\title{
PRODUCTION AND FOREIGN TRADE IN VEGETABLES IN POLAND
}

\author{
Agnieszka Tarnowska ${ }^{1}, \mathrm{PhD}$; Anna Kowalska ${ }^{2}, \mathrm{PhD}$ \\ 1,2 Wroclaw University of Economics
}

\begin{abstract}
Vegetables are an important part of the diet, but their consumption is still too low. An increase in demand for these crops is expected. Poland has large resources of land and work in agriculture, which is inefficient. Growing vegetables is a competitive branch of Polish agriculture. Their share in the global crop production in Poland has been steadily increasing. The aim of the study was to analyse and evaluate changes in the production and foreign trade in vegetables in Poland. The analysis showed that the area of vegetable cultivation decreased in the period $2000-2016$ by $26.3 \%$. Production decreased by $2 \%$. In the production structure, more expensive qualitative vegetables displace cheaper volumetric vegetables. The observed increase in Polish vegetable exports was halted by the Russian embargo. The largest recipient of Polish vegetables is Germany, the largest supplier - Spain. Since 2012, the export coverage ratio (TC) has been increasing only in the exchange of Poland with the new EU Member States. The intra-industry trade indicator showed a declining trend. The Polish trade in vegetables is dominated by vertical exchange with low-value products. Since 2015, the marginal share of high-quality products has been seen in trade. The share of horizontal exchange of vegetables is decreasing. Poland exports cheap vegetable products and imports more expensive. In recent years, the development of Polish vegetable sector has been stopped.
\end{abstract}

Key words: vegetables, Poland, production, intra-industry trade.

JEL code: Q11, Q17

\section{Introduction}

Vegetables are a very important component of a healthy and varied diet. In addition to calories, they provide vitamins and minerals. The most valuable are C, A and E vitamins, from minerals sodium, potassium, calcium and magnesium. Pro-health activities are attributed to phytochemicals present in vegetables (especially those with antioxidant effects), as well as fibre. A diet rich in vegetables reduces the risk of developing cardiovascular diseases and some cancers (Wang X. et al., 2014; Hjartaker A. et al., 2015; Slavin J. L. and Lloyd B., 2012).

The need for regular consumption of vegetables is increasingly promoted (Fisher J. O. and Dwyer J. T., 2016). Experts in the field of nutrition and prevention of chronic diseases for years recommend eating 400 grams of fruit and vegetables every day or five servings (FAO, 2015). In the European Union, 5 or more servings of fruit and vegetables are consumed daily by $14.3 \%$ of the population, and $34.4 \%$ do not eat them at all. This is a problem mainly for the new Member States. Over half of the respondents in Bulgaria and Romania did not eat any fruit or vegetables, in Poland - $33.2 \%$ (Eurostat, 2017).

Considering two three-year periods, 2001-2003 and 2011-2013, it was noted that the average annual vegetable consumption in the world increased from 115.9 to $138.6 \mathrm{~kg}$ per capita, dropping in the EU from 119.0 to $112.1 \mathrm{~kg}$ per capita and in Poland from 121.8 to $119.0 \mathrm{~kg}$ per capita (FAOSTAT, 2018). However, the increase in the population in Poland caused that, according to the balances, the average annual consumption of vegetables in the years 2001-2003 amounted to 3.9 million tonnes, and in the years 2013-2015 it increased to 4.4 million tonnes. The degree of selfsufficiency of vegetables in these years increased slightly from 106.4 to 106.7 (Rocznik rolnictwa..., 2007, 2016).

The global demand for vegetables in Poland increased and the level of coverage of this demand by domestic production also increased slightly. There are, therefore, surplus vegetables that can be exported. Observing the greater awareness and tendency of the Polish society to eat healthy food, 
it can be assumed a further increase in the demand for vegetables, which will also increase their production.

The aim of the study is to analyse and evaluate changes in the production and foreign trade of vegetables in Poland. The study covered the sown area, production volume and its structure. Next, the coverage level of imports by export and the intensity of intra-industry trade with vegetables were analysed. It was decided to verify the hypothesis about the growing competitiveness of Polish vegetables on the European market.

\section{Material and methods}

In the part of the publication devoted to the area of cultivation, production volumes and their structure, the data of FAOSTAT, Eurostat and the Central Statistical Office in Poland (CSO) were used. In the part concerning foreign trade, data from the International Trade Statistics database were used. The indexes of dynamics, structure, trade coverage and intensity of intra-industry trade (IIT) were calculated.

The trade coverage ratio - TC (1) is the ratio of the value of exports to the value of imports (Olszanska A., 2016). It shows the extent to which export receipts cover expenses incurred on the import of products from the same category.

$$
\mathrm{TC}=\frac{X}{M}
$$

where:

$X$ - volume / value of exports,

$M$ - volume / value of imports.

The Grubel and Lloyd index was used (Grubel, H.G., Lloyd, P.J., 1975), being the most popular measure of the intensity of intra-industry trade (2), and its transformation proposed by Greenaway, Hine and Milner (1994), which shows the diversity of exchange streams horizontal $(H)$ and vertical $(\mathrm{V}),(3)$ :

$$
G L=1-\frac{\sum_{j=1}^{n}\left|X_{j}^{i}-M_{j}^{i}\right|}{\sum_{j=1}^{n}\left(X_{j}^{i}+M_{j}^{i}\right)}(2) \quad \longrightarrow L=1-\left(\frac{\sum_{j=1}^{n}\left|X_{i}^{H}-M_{i}^{H}\right|+\sum_{j=1}^{n}\left|X_{i}^{V L}-M_{i}^{V L}\right|+\sum_{j=1}^{n}\left|X_{i}^{V H}-M_{i}^{V H}\right|}{\sum_{j=1}^{n}\left(X_{i}+M_{i}\right)}\right)
$$

where:

$X$ - volume / value of exports,

$M$ - volume / value of imports,

i - product,

j - country,

VH - vertical with higher quality,

$\mathrm{VL}$ - vertical with lower quality.

The GL index value ranges from 0 to 1 . The value 1 means that there is only intra-industry trade, while 0 - that there is no such trade. Because intra-industry trade consists of various streams, in the empirical study, its division into horizontal and vertical exchange was taken into account (Sledziewska K., Czarny E., 2015). In the case of products of varying quality, it is important whether the given country exports higher quality products than imports, or the exported products are of a lower quality than those imported. In the first case, it concerns high-quality vertical trade $(\mathrm{VH})$, and in the second - low-quality vertical exchange $(\mathrm{VL})$. In horizontal trade $(\mathrm{H})$, goods of identical quality are exchanged but they differ in non-quality features that are important 
to the buyer. They are so-called visible features. In the case of vegetables, the horizontal exchange covers the ones that are not grown in a given climate, so they must be imported.

\section{Research results and discussion}

\section{Changes in the area, production and structure of vegetables grown in Poland}

Poland has a large production potential in agriculture, related to land and labour resources. In 2014, the area of agricultural land in Poland was $14.6 \mathrm{mln}$ ha, and the number of people professionally active in agriculture $-2.6 \mathrm{mln}$ people. These resources constituted, in turn, $7.7 \%$ of UAA and $28.1 \%$ of labour resources in the Community (Rocznik rolnictwa..., 2016). Polish agriculture is perceived as not very competitive against modern and efficient Western European agriculture. The production of vegetables, however, develops relatively well and can distinguish Poland on European and even global market (Filipiak T., 2014). The CSO data confirm that vegetable cultivation is increasingly important branch of agricultural production in Poland. The share of vegetables in global crop production increased in the period 2000-2015 in value terms from $11.6 \%$ to $19.0 \%$ (Rocznik rolnictwa..., 2007-2016).

In 2016, the area of vegetable cultivation in the world amounted to $61.8 \mathrm{mln}$ ha and increased by $15.9 \mathrm{mln}$ ha, i.e. $34.6 \%$ (Fig. 1). The reverse situation was observed in the EU and in Poland. Vegetable cultivations stretched there respectively on the area of 2.266 .8 thous. ha and 184.3 thous. ha. This area has decreased in the EU since the beginning of the century (by 535.7 thous. ha, i.e. $18.7 \%$ ) and in Poland (by 65.8 thousand ha, i.e. $26.3 \%$ ).

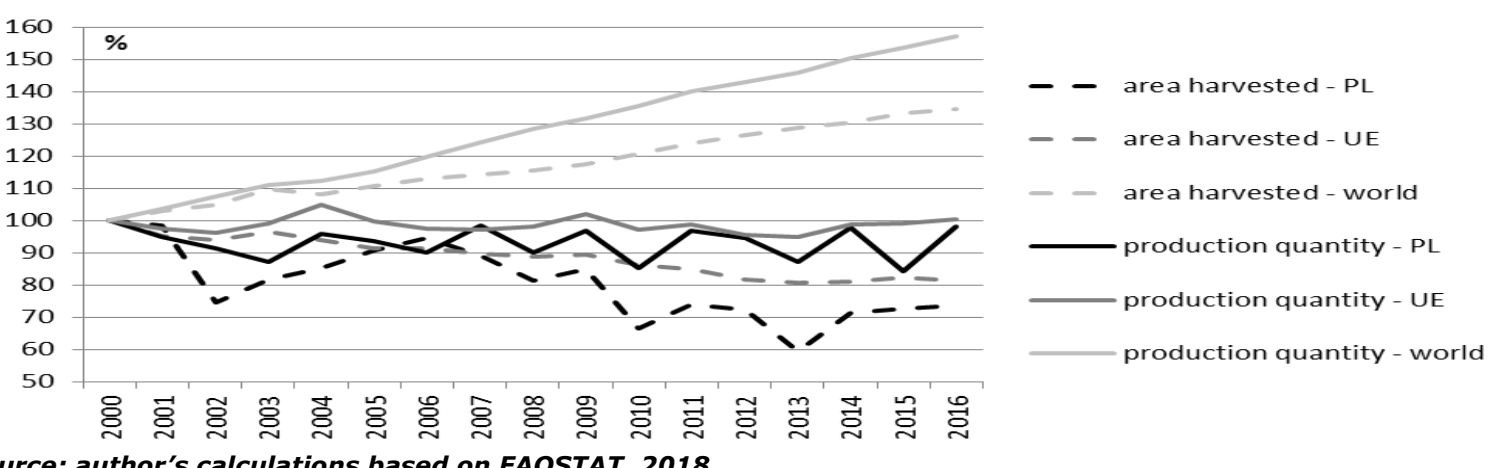

Source: author's calculations based on FAOSTAT, 2018

Fig. 1. Changes in the area of crops and the volume of vegetable production in Poland, the EU and the world in the years 2000-2016 $(w \%, 2000=100)$

According to the most up-to-date farm structure survey (2013), there were almost 920 thous. entities engaged in cultivating vegetables in the EU, including $15.4 \%$ in Poland. The average area of a vegetable farm in the Community was 1.7 ha, in Poland -1.3 ha. Almost half of the vegetable growing area in the EU (47.2\%) was located in three Member States: Italy (19.5\%), Spain $(16.6 \%)$ and Poland $(11.1 \%)$. Poland has the largest area in the EU for growing organic vegetables (16.9 thousand ha, i.e. $19.8 \%$ of the EU area of these crops), (Eurostat, 2016).

In Poland, there were large fluctuations in the area of vegetable crops, from 250.1 thous. ha in 2000 to 148.5 thous. ha in 2013. As a rule, this was related to the purchase prices of vegetables occurring in the seasons preceding production. In 2002, smaller area was the result of data correction after the census. In 2010, the decrease in space was caused by methodological changes. The herbs were excluded from these crops (Kulikowski R., 2013). In 2013, rainy spring caused flooding of the plantation and loss of a part of the crop. The increase in vegetable prices encouraged farmers to develop cultivation. Since 2013, an increase in the area devoted to vegetable crops has been observed. 
In 2000, the largest area was occupied by growing cabbages, onions, carrots and cucumbers. In total, it was 145.6 thous. ha, i.e. $58.2 \%$ of all vegetables grown in Poland (Fig. 2). The cultivation of tomatoes and cauliflowers was of lesser importance (together they covered 34.1 thousand ha and $13.7 \%)$. The other vegetables occupied in total 70.3 thous. ha (28.1\%). In 2016, the area of cultivation was smaller than at the beginning of the century in case of 10 out of 16 analysed vegetable groups. A large reduction was recorded for basic crops. There were limited sowing areas of cabbage (by $50.2 \%$ ), onions (by $25.7 \%$ ), carrot (by $35.3 \%$ ) and cucumbers $(45.2 \%$ ). This meant that the total area of these 4 species was reduced to 87.7 thous. ha, i.e. $47.6 \%$ of the total area of vegetable cultivation. Tomatoes and cauliflowers were grown on a smaller area (25.3 thous. ha), but their share remained the same $(13.7 \%)$. Within 17 years, the proportions between basic and other vegetables have clearly changed in the area structure. The share of the latter increased to $38.7 \%$ (although the area increased by only 1 ha). In total, in 2016 they occupied 25.3 thous. ha, i.e. $76.2 \%$ more than in 2000 . The changes which are taking place indicate growing species diversity of vegetables cultivated in Poland.

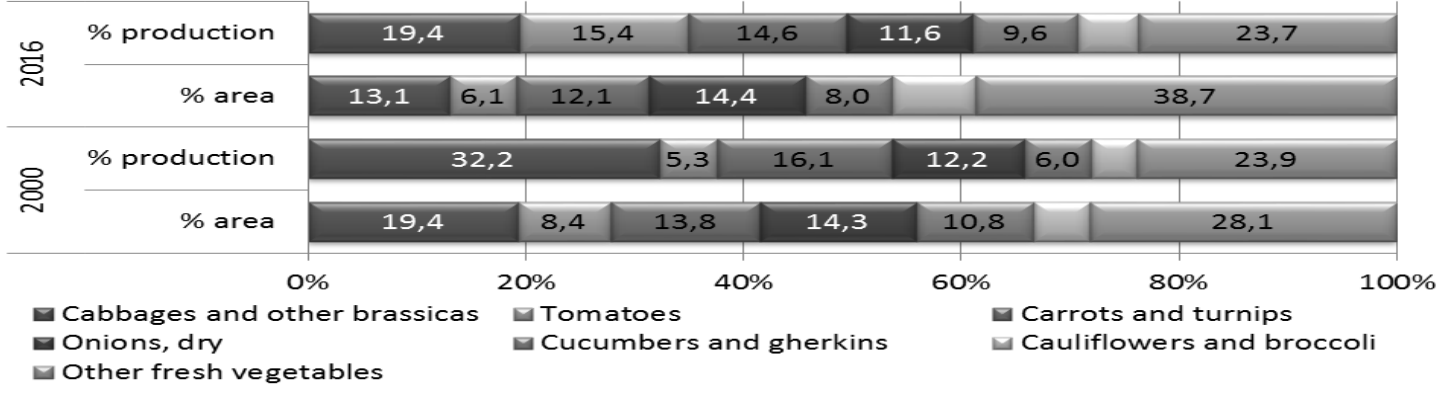

Source: author's calculations based on FAOSTAT, 2018

Fig. 2. Structure of cultivation area and vegetable production volume in Poland in 2000 and 2016 (in \%)

Vegetable production in the world amounted to $1223 \mathrm{mln} \mathrm{t}$ in 2016 and increased by $57.1 \%$ compared to 2000 (Fig. 1). In the EU, $69.3 \mathrm{mln}$ t were produced and the increase was insignificant $(0.2 \%)$. In Poland, $5.9 \mathrm{mln} t$ of vegetables were harvested. It was $2.0 \%$ less than at the beginning of the century. Compared to changes in the area of cultivation, the decrease in production was small. Throughout the whole analysed period, production fluctuated constantly and changed in the range from $6.0 \mathrm{mln} t$ in 2000 to $5.1 \mathrm{mln} \mathrm{t} \mathrm{-} \mathrm{in} 2010$. However, the coefficient of volatility at the level of $5.2 \%$ indicates relatively small fluctuations. In recent years, the reasons for the decline in production have been unfavourable weather phenomena. In 2013, there were flooding of crops, and in 2015 - a huge drought.

In $2000,32.2 \%$ of the production volume was cabbages (Fig. 2). The next, carrot and onion accounted for $28.3 \%$. The important crops also included cucumbers, tomatoes and cauliflowers ( $15.5 \%$ in total). The other vegetables accounted for $23.9 \%$. In 2016, the shares of the basic vegetables in their overall production spread more evenly. It can be noticed that volumetric vegetables (cabbage, carrots) lost their importance in production and the role of qualitative vegetables (tomatoes, cucumbers) increased.

It is worth noting that the value of global plant production in Poland in the period 2000-2015 increased by $65.9 \%$, in which the value of vegetables - by $173.1 \%$ to PLN 9.4 bn.

\section{Poland's competitiveness in international trade with vegetables}

Polish foreign trade, like the entire vegetable sector, have been recording a positive balance in terms of value for many years (Fig. 3). In 2016, Poland sold abroad vegetables worth almost EUR 
$873.4 \mathrm{mln}$, which is almost $231 \%$ more than in 2001 . In almost the entire period under consideration, both exports and imports of vegetables grew (in terms of value). The exception was vegetable export in 2009 (lower by EUR $112.7 \mathrm{mln}$ compared to 2008) and a declining trend visible from 2014 (the value of export decreased compared to 2013 by EUR $29.1 \mathrm{mln}$ ). In the case of vegetables import, its reduced value was recorded in 2009 and 2012. Compared to the previous year, it was lower respectively by EUR $48.5 \mathrm{mln}$ and EUR $67.1 \mathrm{mln}$. The decreasing value of export and import in 2009 was caused by the growing global economic crisis.

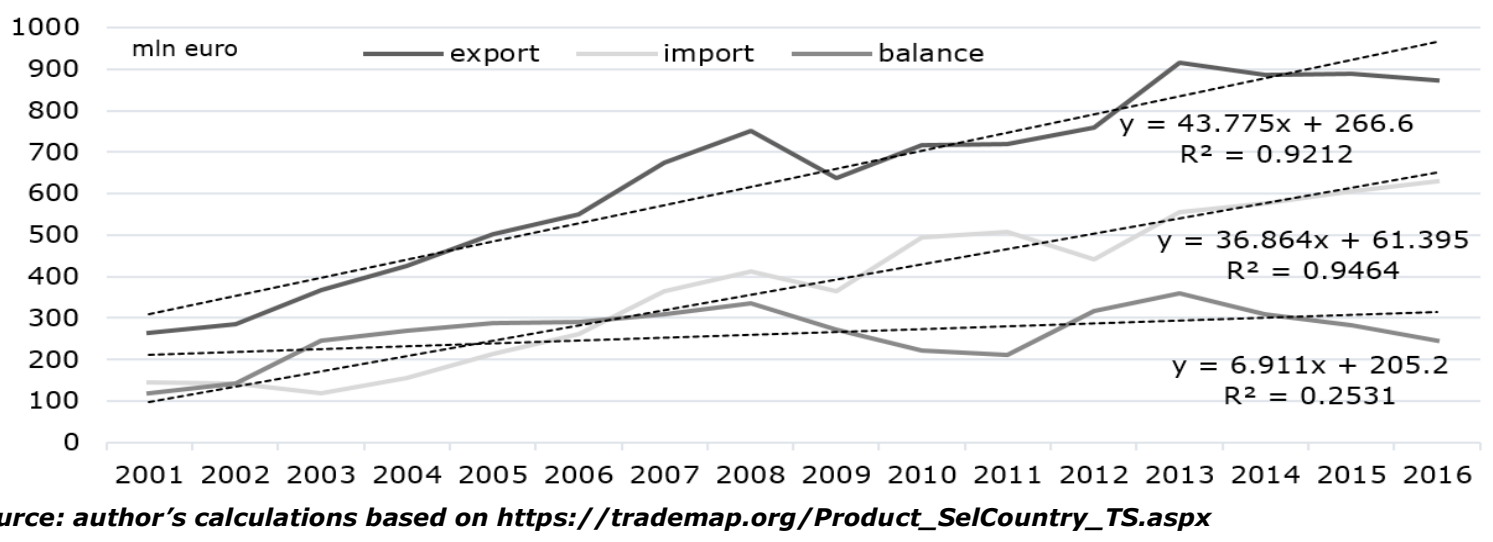

Fig. 3. The value of turnover of Polish foreign trade in vegetables and their products in 2001-2016 (in EUR mln)

The largest positive balance in foreign trade in total vegetables was recorded in 2013 (EUR $359.6 \mathrm{mln}$ ), the smallest - in 2001 (EUR $119.1 \mathrm{mln}$ ). The increase in vegetable exports was related to the accession of Poland to the EU and entry into the Community market. However, the declining vegetable export after 2013 is, among others, the effect of the embargo imposed by Russia on vegetables and fruits from the EU, including Poland. Reducing vegetable markets contributed to the growth of their supply in the EU and forced the price war between manufacturers. Polish vegetables found recipients mainly in EU countries, i.e. Germany, Spain, the Czech Republic and the United Kingdom. Analysis of the trend line showed that the average annual increase in the value of export in period 2001-2016 (at R2 = 0.92) amounted to almost EUR $43.8 \mathrm{mln}$ euros, while import - EUR $36.86 \mathrm{mln}(\mathrm{R} 2=0.95)$.

The highest value of foreign trade turnover of vegetables and their products is obtained by Poland from exports to the EU. Among the EU countries, Germany, France, Great Britain, the Czech Republic and the Netherlands were the largest recipients of Polish vegetables (Tab. 1). Exports to the German market in 2001-2016 accounted for over 1/5 of the entire Polish export of vegetables and their products. In terms of value, the most was exported to Germany:

- other vegetables, fresh or chilled (excluding potatoes, tomatoes, alliaceous vegetables etc.);

- vegetables, uncooked or cooked by steaming or boiling in water, frozen;

- dried vegetables, whole, cut, sliced, broken or in powder, but not further prepared.

The share of these three product groups (in terms of value) was from 85.15 to $92.36 \%$ of all vegetables exported to Germany in the period under consideration.

The largest importer of vegetables from Poland is Germany (in 2016 - EUR $197.2 \mathrm{mln}$ ), but the highest dynamics of export value in 2001-2016 was recorded by Norway (from EUR 79.0 thous. to EUR $11.7 \mathrm{mln}$, ie. by $14642 \%$ ). Since 2014, growing export of vegetables to Belarus has been visible, which may confirm the suspicion of re-export of Polish vegetables by this country to Russia. 
Among the largest importers of Polish vegetables before joining the EU, apart from Germany, France and the Czech Republic, were the Netherlands, Russia and Italy.

Poland imports vegetables mainly from Spain, the Netherlands and Germany. In 2016, import from Spain accounted for $1 / 3$ of the total Polish import of vegetables. Poland buys from Spain mostly unprocessed (fresh or chilled) products, i.e. tomatoes (in 2016 - almost 50 t worth EUR $56.3 \mathrm{mln}$ ) and other vegetables (in $2016-49.6 \mathrm{t}$ worth EUR $68.6 \mathrm{mln}$ ).

The largest exporters and importers of vegetables and their products in terms of value $(\%)$

\begin{tabular}{|c|c|c|c|c|c|c|c|c|c|c|c|c|}
\hline$\dot{0}$ & 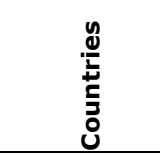 & ¿̊. & 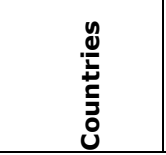 & ষ্ণ & 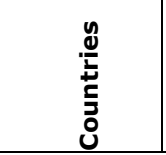 & ¿̊̀ & 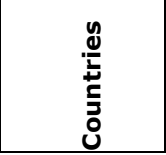 & 울 & 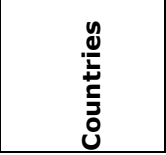 & $\stackrel{m}{\stackrel{m}{*}}$ & 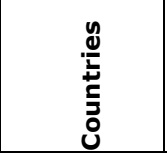 & ํ. \\
\hline \multicolumn{13}{|c|}{ Importers } \\
\hline 1 & Germany & 32.5 & Germany & 27.6 & Germany & 21.8 & Germany & 21.2 & Germany & 21.2 & Germany & 22.6 \\
\hline 2 & Netherlands & 15.2 & Netherlands & 15.6 & UK & 13.0 & Russia & 16.7 & Russia & 19.0 & UK & 13.6 \\
\hline 3 & Russia & 6.7 & UK & 7.0 & Netherlands & 11.3 & UK & 10.7 & UK & 10.8 & France & 8.2 \\
\hline 4 & France & 6.5 & France & 5.9 & France & 8.4 & France & 7.8 & France & 6.9 & Belarus & 7.0 \\
\hline 5 & Italy & 6.5 & Czech Rep. & 5.9 & Czech Rep. & 7.2 & Netherlands & 7.3 & Czech Rep. & 4.2 & Czech Rep. & 5.1 \\
\hline 6 & Czech Rep. & 6.1 & Italy & 3.4 & Russia & 6.8 & Czech Rep. & 4.6 & Italy & 3.8 & Netherlands & 4.7 \\
\hline \multicolumn{13}{|c|}{ Exporters } \\
\hline 1 & Spain & 40.0 & Spain & 40.7 & Spain & 34.9 & Spain & 28.4 & Spain & 34.0 & Spain & 31.7 \\
\hline 2 & Netherlands & 18.9 & Netherlands & 17.2 & Netherlands & 17.6 & Netherlands & 20.3 & Netherlands & 15.9 & Netherlands & 17.3 \\
\hline 3 & China & 7.8 & China & 5.9 & Germany & 10.0 & Germany & 11.0 & Germany & 14.2 & Germany & 11.4 \\
\hline 4 & Hungary & 6.6 & Italy & 5.7 & Italy & 8.5 & Italy & 7.5 & Italy & 8.0 & Italy & 7.9 \\
\hline 5 & Italy & 6.5 & Germany & 4.8 & China & 6.4 & China & 5.2 & China & 4.1 & China & 5.3 \\
\hline 6 & Belgium & 3.6 & Hungary & 3.7 & France & 2.9 & France & 4.4 & Morocco & 3.0 & \begin{tabular}{|l} 
Belgium \\
\end{tabular} & 3.1 \\
\hline
\end{tabular}

Source: author's calculations based on https://trademap.org/Product_SelCountry_TS.aspX

The next step in the analysis was to calculate the TC index. It tells what part of the import expenditure is covered by revenues from exports. It also directly determines the scale of the trade surplus, and indirectly - the economic benefits of exchange. The TC index value in the years 20012016 fluctuated considerably (Fig. 4).

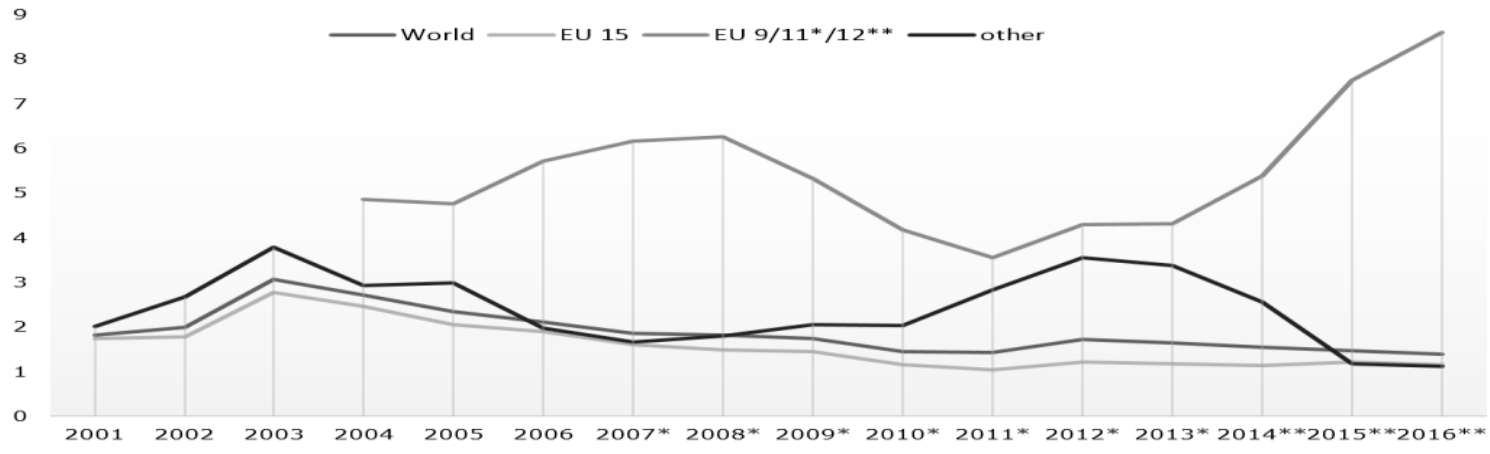

Source: author's calculations based on https://trademap.org/Product_SelCountry_TS.aspx

Fig. 4. Trade coverage ratio (TC) of vegetables and their products from Poland in general and by EU 15, EU 13 and outside EU countries

In the whole of the analysed period, the TC index showed values above 1, both in the exchange with the world, as well as with the selected groups of countries. This means a comparative advantage in the field of vegetable trade. In the case of the world, as well as the EU 15, this advantage decreased every year. However, in the exchange with non-EU countries, it began to 
decrease since 2012. Poland gains the largest advantage in trade with vegetables with new EU countries, especially since 2011.

The study of intra-industry trade (Tab. 2) shows the effects of Poland's integration with the European Union countries, and more specifically with the EU 15. Quite systematically, the IIT shares grew since 2004, although the growth rate was declining. In the years 2003-2007, intratrade with the EU countries increased by 36 pp., while with EU 15 - increased by $33 \mathrm{pp}$. (in the years 2003-2006). The decline in the index is visible during the crisis years (2007-2009). In subsequent years, the index also showed a declining trend: with slight changes in 2013 and 2015 for the entire EU and in 2009 and 2011 for the EU 15. IIT indicators in trade with EU 15 countries are permanently higher than indicators obtained in vegetable exchange both with new Community countries as well as with non-EU countries.

Table 2

Indicators of Polish intra-industry trade (IIT) in vegetables and its products with EU and non EU countries in 2001-2016

\begin{tabular}{|c|c|c|c|c|c|c|c|c|c|c|c|c|c|c|c|c|}
\hline $\begin{array}{l}\text { Specifi- } \\
\text { cation }\end{array}$ & ¿-1 & N & mo & ষ & $\begin{array}{l}\text { n̊ } \\
\text { 유 }\end{array}$ & \begin{tabular}{l}
0 \\
$:$ \\
\hdashline
\end{tabular} & $\stackrel{*}{\stackrel{*}{O}}$ & 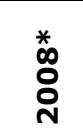 & $\begin{array}{l}\text { * } \\
\text { ○े } \\
\text { 오 }\end{array}$ & $\begin{array}{l}\text { * } \\
\text { o } \\
\text { ○ं } \\
\text { N }\end{array}$ & $\begin{array}{l}\stackrel{*}{*} \\
\stackrel{-}{0} \\
\stackrel{N}{N}\end{array}$ & 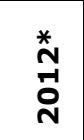 & $\begin{array}{l}\stackrel{*}{*} \\
\stackrel{*}{M} \\
\stackrel{\sim}{N}\end{array}$ & $\begin{array}{l}\stackrel{*}{*} \\
\stackrel{*}{+} \\
\stackrel{-}{\mathbf{N}}\end{array}$ & $\begin{array}{l}\stackrel{*}{*} \\
\stackrel{*}{*} \\
\text { ñ } \\
\text { ○े }\end{array}$ & $\begin{array}{l}* \\
\stackrel{*}{*} \\
6 \\
-1 \\
\text { ㅇ }\end{array}$ \\
\hline $\begin{array}{l}\text { EU, in } \\
\text { which: }\end{array}$ & 0.73 & 0.73 & 0.63 & 0.70 & 0.84 & 0.90 & 0.99 & 0.99 & 0.98 & 0.81 & 0.77 & 0.84 & 0.78 & 0.79 & 0.85 & 0.83 \\
\hline - EU 15 & .73 & 0.73 & 0.63 & 0.78 & 0.94 & 0.96 & 0.79 & 0.73 & 0.79 & 0.66 & 0.63 & 0.70 & 0.59 & 0.58 & 0.56 & 0.56 \\
\hline $\begin{array}{l}\text { - EU } \\
9 / 11 * / 13 \\
* *\end{array}$ & $x$ & $x$ & $x$ & 0.34 & 0.35 & 0.30 & 0.28 & 0.28 & 0.32 & 0.39 & 0.44 & 0.38 & 0.38 & 0.31 & 0.23 & 0.21 \\
\hline $\begin{array}{l}\text { Non-EU } \\
\text { counties }\end{array}$ & 0.66 & 0.52 & 0.32 & 0.25 & 0.23 & 0.25 & 0.26 & 0.25 & 0.29 & 0.34 & 0.28 & 0.25 & 0.23 & 0.28 & 0.32 & 0.38 \\
\hline
\end{tabular}

Source: author's calculations based on https://trademap.org/Product_SelCountry_TS.aspx

The study also shows the effect of trade shift. In 2009-2011, the IIT indicator in the exchange with the EU 15 decreased by a value close to the increase of this indicator in exchange with the new Member States. The share of new Member States in commodity exchange with Poland grew even during the collapse of world trade in 2009.

A detailed analysis of Poland IIT broken down into horizontal and vertical trade (Fig. 5) reveals that for the majority of the analysed period, the vertical exchange of low-value vegetables dominated.

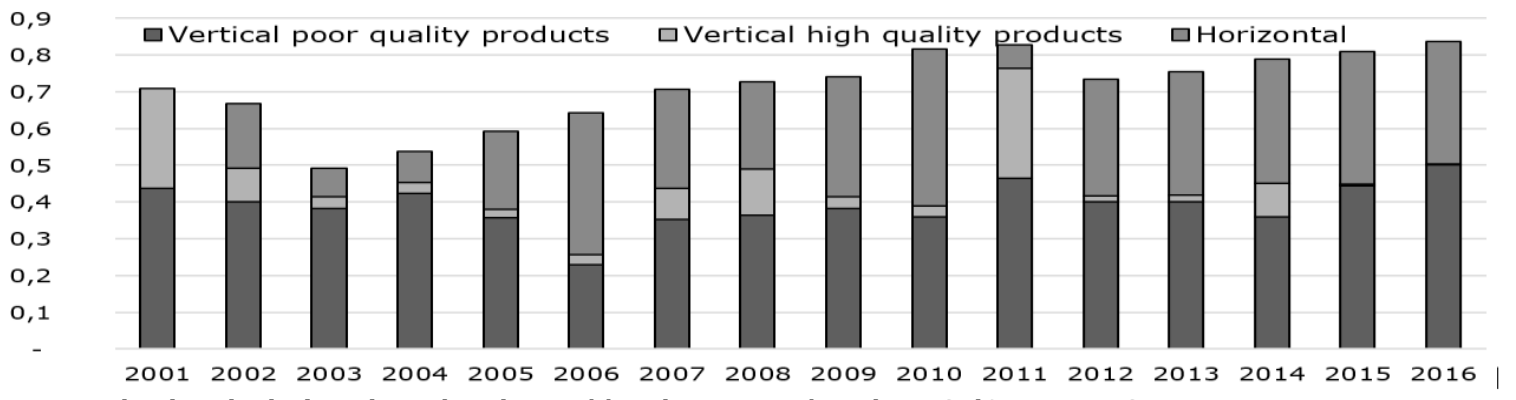

Source: author's calculations based on https://trademap.org/Product_SelCountry_TS.aspX

Fig. 5. Horizontal and vertical intra-industry trade of Poland with the World

Since 2015, in the trade exchange a marginal share or lack of high-quality products is visible and there has been a decreasing share of horizontal exchange of varied vegetables (e.g. those that are not grown in a given country). The growing share of low-cost products in exchange could have been caused by the relation of PLN to EUR and lower costs of vegetable production in Polish 
compared with the EU-15, not necessarily inferior quality. The importers of most Polish vegetables are the EU 15.

\section{Conclusions, recommendations}

1) The area of vegetable cultivation in Poland is the third largest in the EU. Poland also has the largest area of organic vegetable crops. The importance of this branch of agriculture in Poland is growing, despite the fact that in 2000-2016 their area crops decreased by over $1 / 4$. During this time, the production volume decreased by only $2 \%$. This shows the increasing efficiency of this production.

2) The area of cultivation of most basic vegetable species has decreased, in particular: cabbage, onions, carrots and cucumbers (their total area has been reduced by nearly $50 \%$ ). At the same time, the growing species diversity of vegetables grown in Poland was noticed. Volumetric vegetables (cabbage, carrots) lost importance, and the role of qualitative vegetables (tomatoes, peppers) grew.

3) In Poland, in the years 2000-2015, the value of global vegetable production increased by $173.1 \%$ (to PLN 9.4 billion). This results, among others, from the increase in the production of qualitative vegetables, which are more expensive.

4) The vegetable market in Poland is unstable, as evidenced by large fluctuations in production volume and crop area. Small farms, which are mainly vegetable producers, are not able to supply large and uniform batches of vegetables. They should associate producer groups and develop large-scale production of vegetables under covers.

5) Poland is actively involved in foreign trade in vegetables in the EU and has reported a positive turnover balance in the analysed years. The growing variety of grown vegetables and their attractive prices in relation to quality make the Polish vegetable sector more and more competitive in the EU, and recently also outside it.

6) In the study of intra-industry trade, positive effects of Poland's accession to the EU were visible. For Poland, the EU 15 countries are the most important partners for mutual exchange of vegetables.

7) Poland exports mainly cheap vegetables, although of good quality. The price of Polish vegetables is influenced by the exchange rate of PLN to EUR and USD, as well as lower production costs than in the EU 15 countries,. Thanks to attractive prices, they are also eagerly bought by countries outside the Community, i.e. Belarus, the USA and Norway.

8) Presented analysis and the conclusions drawn from them allow for partial confirmation of the hypothesis set in the introduction. It assumed growing competitiveness of Polish vegetables on the European market. In recent years, exports and participation in the IIT of the EU-15 countries have decreased, but the new EU Member States and Belarus started to buy more Polish vegetables.

\section{Bibliography}

1. Greenaway, D., Hine, R.C., Milner, C. (1994). Country Specific Factors and the Pattern of Horizontal and Vertical Intra-Industry Trade in the United Kingdom, Weltwirtschaftliches Archiv, Vol. 130, No. 1.

2. Grubel, H.G., Lloyd, P. J. (1975). Intra-Industry Trade: The Theory and Measurement of Intra-Industry Trade in Differentiated Products, Macmillan, London.

3. Olszanska, A. (2016). Handel zagraniczny Polski produktami miesnymi w latach 1996-2014 - ocena tendencji na podstawie wybranych wskazników (Foreign trade of Poland with meat products in the years 1996-2014 - evaluation of trends based on selected indicators). Zeszyty Naukowe SGGW w Warszawie. Problemy Rolnictwa Swiatowego, 16(31), No. 2, pp. 232-241. 
4. Sledziewska, K., Czarny, E. (2015). Unia monetarna a intensywnosc wymiany towarowej - studium przypadku strefy euro (Monetary union and the intensity of trade in goods - a case study of the euro area). Acta Universitatis Lodziensis Folia Oeconomica, 5 (316), pp. 113-131.

5. Wang, X., Ouyang, Y., Liu, J., Zhu, M., Zhao, G., Bao, W., Hu, FB. (2014). Fruit and Vegetable Consumption and Mortality from All Causes, Cardiovascular Disease, and Cancer: Systematic Review and Dose-Response Meta-Analysis of Prospective Cohort Studies. British Medical Journal, Volume 349, Issue 5472, pp. 1-14.

6. Hjartaker, A., Knudsen, MD., Tretli, S., Weiderpass, E. (2015). Consumption of Berries, Fruits And Vegetables and Mortality Among 10,000 Norwegian Men Followed for Four Decades. European Journal of Nutrition, Volume 54, Issue 4, pp. 599-608.

7. Slavin, J. L., Lloyd B. (2012). Health Benefits of Fruits and Vegetables. Advances in Nutrition, Volume 3, Issue 4, pp. 506-516.

8. Fisher, J. O., Dwyer J. T. (2016). Next Steps for Science and Policy on Promoting Vegetable Consumption among US Infants and Young Children. Advances in Nutrition Adv Nutr vol. 7, Issue 1. pp. 261S-271S.

9. Promotion of Fruit and Vegetables for Health. Report of the Pacific Regional Workshop (2015). Rome: FAO, p. 3.

10. Eurostat. Retrieved: http://ec.europa.eu/eurostat/data/database. Access: 15.12.2017.

11. Eurostat. The fruit and vegetable sector in the UE - a statistical overview. Retrieved: http://ec.europa.eu/eurostat/statisticsexplained/index.php/The_fruit_and_vegetable_sector_in_the_EU_-_a_statistical_overview\#Consumption. Access: 17.12.2017.

12. Kulikowski, R. (2013). Produkcja i towarowosc rolnictwa w Polsce. Przemiany i zroznicowania przestrzenne po II wojnie światowej (Production and commodity of agriculture in Poland. Transformations and spatial differentiation after World War II). Polska Akademia Nauk - Instytut Geografii i Przestrzennego Zagospodarowania, Warszawa, p. 45.

13. Filipiak, T., (2014). Zmiany na rynku warzyw $i$ w gospodarstwach warzywniczych $w$ Polsce po integracji $z$ Unia Europejska (Changes in the vegetable market and vegetable farms in Poland after integration with the European Union). Wydawnictwo SGGW, Warszawa, p. 7.

14. FAOSTAT. Retrieved: http://www.fao.org/faostat/en/\#data. Access: 10.12.2017. 